\title{
Central Mechanisms of Tremor in Some Feline and Primate Models
}

\author{
Y. LAMARRE, A. J. JOFFROY, M. DUMONT, C. DE MONTIGNY, F. GROU and J. P. LUND
}

SUMMARY: For several years our interest has been in a postural Parkinsonlike tremor at 4-6/sec. which can be produced in the monkey by lesions of the central nervous system. We have also studied the effects of harmaline, a drug which evokes or intensifies the Parkinson-like tremor in lesioned animals and which also induces a fine, generalized tremor at 7-12/sec. in normal animals. The results obtained so far

RÉSUMÉ: Depuis plusieurs années nous avons étudié les mécanismes physiopathologiques responsables d'un tremblement exnérimontal apparaissant chez le Singe à la suite de lésions du tegmentum mésencéphalique. Ce type de tremblement présente des caractéristiques cliniques et électromyographiques identiques à celles du tremblement parkinsonien. Le tremblement expérimental de type parkinsonien est difficile à reproduire chez le Singe. Cependant, l'harmaline fournit un modèle intéressant de tremblement d'origine centrale. Cette substance provoque un tremblement ample et alterne à la fréquence de 3 à $6 / \mathrm{sec}$. chez le Singe porteur de lésions du tronc cérébral. De plus, chez le Singe normal ainsi que chez le Chat l'harmaline induit un tremblement fin, généralisé et non alterne à la fréquence de 7 à $12 / \mathrm{sec}$. Nos travaux récents sur l'origine du tremblement de indicate that these two types of tremor are generated by two independent central mechanisms which do not require the integrity of peripheral feedback loops. The experimental Parkinson-like tremor is generated by a thalamocortical mechanism while the olivocerebellar system is responsible for the faster "physiological" tremor. Similar tremor mechanisms may be involved in some movement disorders in man.

type parkinsonien ainsi que sur le mode d'action de l'harmaline nous ont conduits à formuler certaines hypothèses concernant la nature des mécanismes trémorogènes centraux. Ainsi, nous pensons qu'un système thalamo-cortical agit, dans certaines conditions anormales, comme un véritable pacemaker responsable $d u$ tremblement de type parkinsonien. Quant à l'action de l'harmaline, elle s'établirait au moins à dèux niveaux: au niveau diencéphalique, en exagérant l'activité thalamique anormale (tremblement de type parkinsonien à 3-6/sec.) et, de façon indépendante, au niveau bulbaire, en exagérant la tendance rythmique normale du système olivo-cérébelleux (tremblement à 7-12/sec.). Nous croyons que ces hypothèses pourraient aussi s'appliquer aux mécanismes responsables de tremblements chez l'Homme.
From the Centre de Recherche en Sciences Neurologiques, Départment de physiologie, Université de Montréal.

Supported by the Medical Research Council of Canada.

Reprint requests to $\mathrm{Dr}$. Y . Lamarre, Départment de physiologie, Université de Montréal, C.P. 6208 , Succursale A, Montréal, P.Q., H3C 3T8.

\section{INTRODUCTION}

The physiopathology underlying the movements of tremor in man is still poorly understood. There are obvious limitations on the studies of human tremors. Research on experimental models could contribute meaningful information on the central mechanisms of abnormal movements in man and possibly lead to the discovery of more effective and specific treatment for such disorders.

For several years our interest has been in a postural Parkinson-like tremor which can be produced in the monkey by lesions of the ventromedial tegmentum of the brain stem, (Poirier, 1960; Poirier, 1971), and also of the lateral cerebellar system (Goldberger and Growden, 1971; Larochelle, Bédard, Boucher and Poirier, 1970; Lamarre and Dumont, 1972).

The tremor movements made by these monkeys appear to be similar and closely related to those seen in patients with Parkinsonian tremor, (Cordeau, Gybels, Jasper and Poirier, 1960; Lamarre and Cordeau, 1967). They are reciprocally organized (Fig. 1) and occur at a frequency of around 5/sec. (range 3 to 7). However, only a small number of these operated monkeys show sustained spontaneous tremor. Poirier, Sourkes, Bouvier, Boucher and Carabin (1966) first showed that administration of harmaline (3-5 $\mathrm{mg} / \mathrm{kg}$, i.v.) could be used to produce the tremor in lesioned animals who do not show it spontaneously and that it may also exacerbate existing tremor. In normal monkeys, harmaline does not produce $5 / \mathrm{s}$ Parkinson-like tremor. Instead, it induces a faster, finer generalized tremor at 7-12/s (Poirier et al., 1966), 


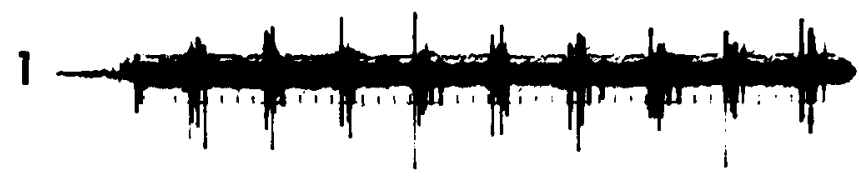

2

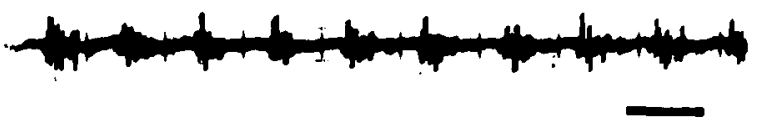

Figure 1-EMG recordings from the upper limb in a monkey with Parkinson-like tremor following a contralateral midbrain tegmental lesion. Grouping of muscle potentials at $5 / \mathrm{sec}$. occurs regularly and reciprocally in antagonistic muscles $(1=$; Biceps; 2 =triceps). The time scale is $200 \mathrm{msec}$.

Figure 2-Autocorrelograms of a neuron recorded in the VL of a paralyzed, unanesthetized cat. A: Regular 5/sec. bursting during reinforcement by motor cortex "auto-stimulation". B: Spontaneous bursting at about $3.4 / \mathrm{sec}$. Note that during

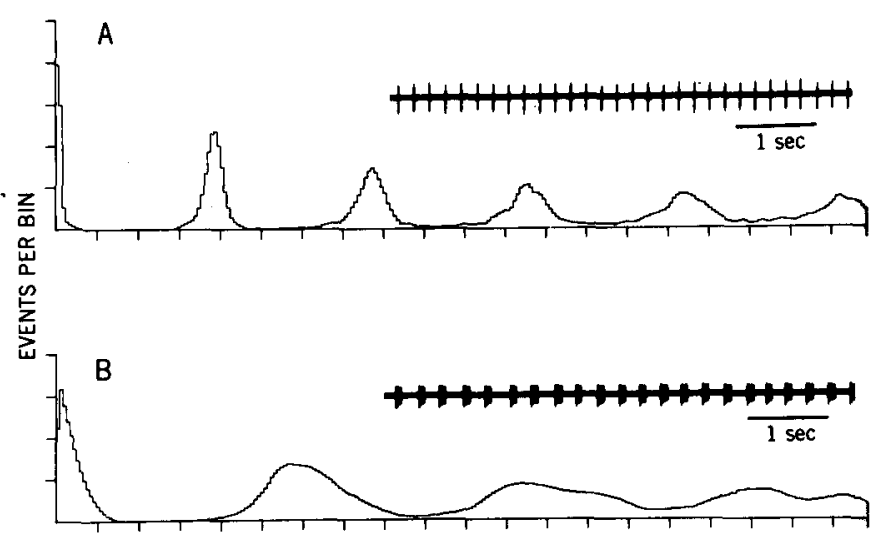

$50 \mathrm{msec} / \mathrm{DIV}$

motor cortex stimulation the duration of the bursts is shortened (recording samples in $\mathrm{A}$ and $\mathrm{B}$ insets). The ordinate scales are in arbitrary units. which is also demonstrable in the cat following administration of the drug.

In recent years, we have accumulated data showing these two tremors depend on two different and independent neural mechanisms. A thalamo-cortical mechanism appears to be responsible for the Parkinsonlike tremor at 4-6/s while the inferior olive generates the $7-12 / \mathrm{s}$ tremor.

\section{Thalamo-cortical mechanism generating tremor at 4-6/sec.}

Parkinsonian tremor can be diminished or abolished by many neuro-surgical interventions which ablate or destroy cortical or thalamic motor regions. Moreover, single units discharging at the tremor frequency have been recorded in the region of the nucleus ventralis lateralis (VL) in Parkinsonian patients during stereotaxic surgery, (Albe-Fessard, Arfel, Guiot, Derome, De la Herran, Korn, Hertzog, Vourc-h et Aleonard, 1963; AlbeFessard, Guiot and Hardy, 1963; Albe-Fessard, Guiot, Lamarre and Arfel, 1966; Bates, 1969; Crowell, Perret, Siegfried and Villoz, 1968; Hardy and Bertrand, 1966; Jasper and Bertrand, $1966 \mathrm{a}$ and b). The rhythmic discharges of these units could be recorded in either the presence or absence of tremor. Rhythmic slow wave activity at the tremor frequency was also recorded from the somatomotor cortex in Parkinsonian patients by Alberts (1969) and Alberts, Wright and Feinstein
(1969). Old clinical observations by Pollock and Davis (1930) and Walshe (1924) suggested that Parkinsonian tremor does not depend upon sensory feedback from tremor movements. Similarly, Ohye, Bouchard, Larochelle, Bédard, Boucher, Raphy and Poirier (1970) have observed in the monkey that extensive dorsal rhizotomy $\left(C_{2}-T_{4}\right)$ does not abolish the experimental tremor in the deafferented limb, providing further evidence for a central generating mechanism.

In monkeys with Parkinson-like tremor, neurons discharging at the frequency of tremor were first recorded in the sensori-motor cortex by Cordeau et al., (1960). Further studies from this laboratory have shown that, when the tremor is blocked by a curarizing agent, neurons in the motor cortex and in the ventrolateral region of the thalamus continue to discharge at the same frequency as the previously existing tremor, (Cordeau and Lamarre, 1966; Lamarre and Cordeau, 1967; Lamarre and Joffroy, 1970). Following dorsal rhizotomy, a number of cells discharging in relation to the tremor have been found in the cortical representation area of the deafferented trembling limb, (Joffroy and Lamarre, 1971). These units could not be influenced by any peripheral stimuli. Thalamic neurons bursting in relation to tremor in the contralateral deafferented upper limb have also been recorded
(Dumont and Lamarre, unpublished observations). The assumption was then made that if a central mechanism was responsible for the tremor its rhythmic output would not be suppressed by a peripheral block of the movements or by removal of all afferent inputs. These results directly. support the hypothesis that the experimental Parkinson-like tremor in the monkey and perhaps human Parkinsonian tremor is generated by a thalamocortical system.

Thalamic neurons can show rhythmic bursting at the frequency of about $5 / \mathrm{sec}$. in normal unanesthetized monkeys (Joffroy and Lamarre, 1974; Lamarre and Joffroy, 1971). This is most prominent in the nuclei anterior to the ventrobasal complex and always concomitant with a state of relaxation. When the animal is aroused, the bursting disappears and is replaced by continuous firing at $10-30 / \mathrm{sec}$. (Joffroy and Lamarre, 1974). Rhythmic activity of neurons in the VL complex of the thalamus has also been seen in unanesthetized cats by Lamarre, Filion and Cordeau (1971) and in chloralozed cats by Massion, Angault et Albe-Fessard (1965). It can easily be provoked by low frequency $(6-7 / \mathrm{sec}$.) stimulation of non-specific medial thalamic nuclei, (Purpura, 1969, 1972 a and b).

The data now available do not allow definite conclusions about the mechanism responsible for the 


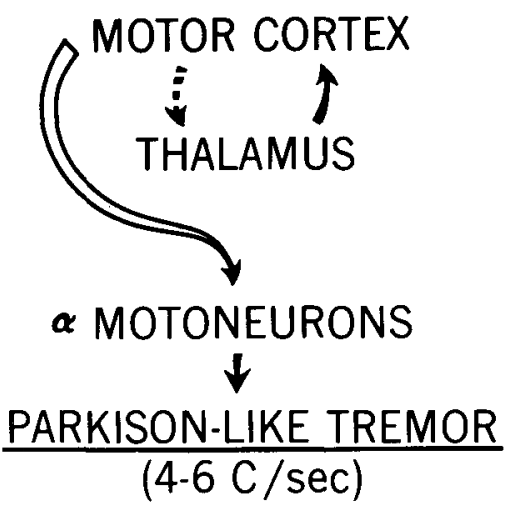

Figure 3-Simplified diagram showing the relationships of structures responsible for the Parkinson-like tremor.

rhythmic bursting of thalamic units. Moreover, it is not known if the motor cortex is merely driven by a thalamic "oscillator" or if both thalamus and cortex are actively involved. Experiments by Leblanc and Cordeau (1969) in unanesthetized cats have shown that the preferential oscillating frequency of the VL-cortex system is $5 / \mathrm{sec}$. This is the frequency of VL stimulation that induces maximal discharge of large pyramidal tract cells in the motor cortex. In the unanesthetized cat (Lamarre and Lund, unpublished observations) we have also demonstrated that the thalamo-corticothalamic reverberating circuits described by Dempsey and Morison (1942) function at a preferential frequency of $5 / \mathrm{sec}$. This is shown in Fig. 2. The spontaneous rhythmic bursting of a VL neuron is characterized by the autocorrelogram in Fig. 2B. This has peaks occurring regularly at approximately $290 \mathrm{msec}$. intervals which would give a frequency of bursts of $3.4 / \mathrm{sec}$., which is in agreement with previous findings reported by Lamarre et al., (1971). The autocorrelogram of Fig. $2 \mathrm{~A}$ was compiled from recordings from the same neuron during stimulation of its axon terminals within the motor cortex. Antidromic activation was followed by transsynaptically induced bursts of action potentials. A single electrical shock (square wave pulse of $0.1 \mathrm{msec}$. duration) to the motor cortex was triggered (delay $5 \mathrm{msec}$.) by a spontaneous VL neuron spike. In these conditions of cortico-thalamic rein- forcement, bursting of the neuron occurs spontaneously at very regular intervals of $190 \mathrm{msec}$. which corresponds to a frequency of $5.2 / \mathrm{sec}$. In monkeys with experimental Parkinson-like tremor it was observed that some thalamic cells which were bursting regularly at the same frequency as the tremor went into bursting at a lower and often irregular manner when the tremor was arrested by cooling the motor cortex, (Jasper, Lamarre and Joffroy, 1972).

These observations raise the possibility that both thalamus and motor cortex are actively involved, possibly by their interconnections, in the genesis of Parkinsonian tremor. From the effects observed following elec-

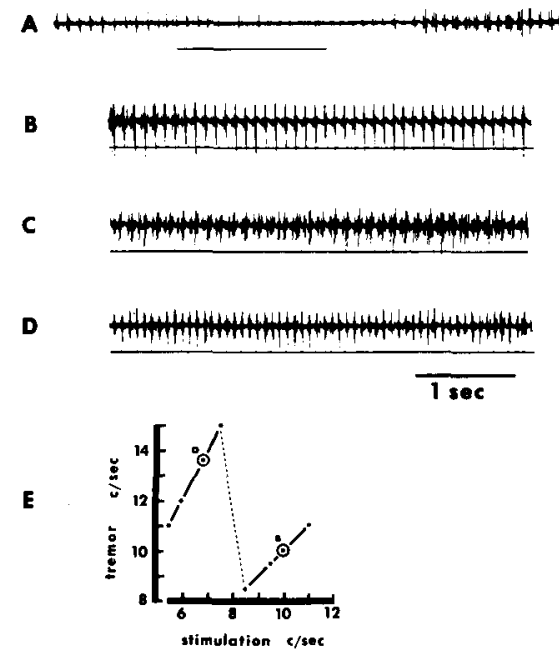

Figure 4-EMG recordings from the quadriceps in a decerebrate, unanesthetized cat injected with harmaline.

A: The spontaneous tremor at $8.5 / \mathrm{sec}$. is inhibited during stimulation (parafastigial) of the olivo-cerebellar system at $50 / \mathrm{sec}$. (indicated by the bar).

B: Stimulation at $10 / \mathrm{sec}$. produces EMG bursts at the same frequency (one to one relationship).

C: Stimulation at $8 / \mathrm{sec}$. produces a mixed, disorganized pattern of muscle activities.

D: Stimulation at $6.8 / \mathrm{sec}$. produces EMG bursts at $13.5 / \mathrm{sec}$. (one to two relationship).

$\overline{\mathrm{E}}$ : Plot of stimulation vs. EMG burst frequencies. There is a one to one relationship between 8 and 12/sec. (slope $=1$ ) and a one to two relationship with stimulus frequencies between 5 and $7.5 / \mathrm{sec}$. (slope $=2$ ).

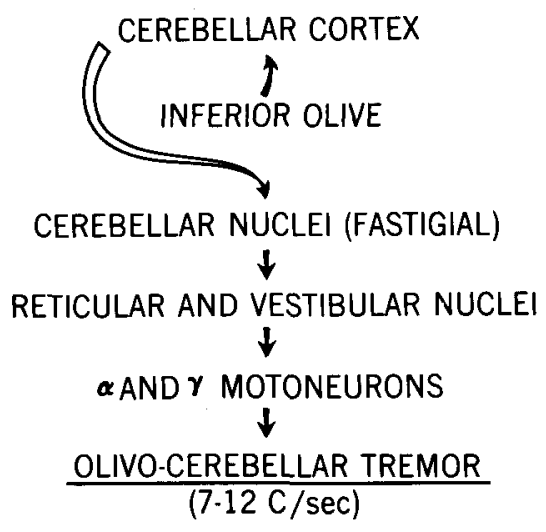

Figure 5-Diagram showing the pathways to the muscles from the tremorgenic site (inferior olive) responsible for the olivo-cerebellar tremor.

trical stimulation of the cortex adjacent to the Rolandic fissure in awake man, Alberts (1972) concluded that the somatomotor cortex itself contains the motor program responsible for Parkinsonian tremor. Our experimental results, however, would suggest the possibility that both thalamus and motor cortex are actively involved and that thalamocortical loops are an essential feature in the genesis of Parkinsonian tremor (Fig. 3).

\section{Olivio-cerebellar mechanism generating tremor at 7-12/sec.}

Olivary neurons show a normal tendency to fire synchronously at 7-12/sec. (Armstrong, Eccles, Harvey and Matthews, 1968; Bell and Kawasaki, 1972; Crill, 1970; Ferin, Gregorian and Strata, 1971; Sedgwick and Williams, 1967). Dendrodendritic electrotonic coupling (King, Martin and Bowman, 1975; Llinas, Baker and Sotelo, 1974; Sotelo, Llinas and Baker, 1974) is probably responsible for the synchronous firing of olivary cells, while the $10 / \mathrm{sec}$. rhythm is imposed by recurrent inhibition lasting approximately $100 \mathrm{msec}$. (Armstrong et al., 1968; Crill, 1970). Harmaline, a carboline derivative, was shown to exaggerate this normal tendency for rhythmicity and synchronization of inferior olivary neurons (Lamarre, De Montigny, Dumont and Weiss, 1971). This action of harmaline generates muscle tremor at $7-12 / \mathrm{sec}$. via the cerebello-bulbar system (De 


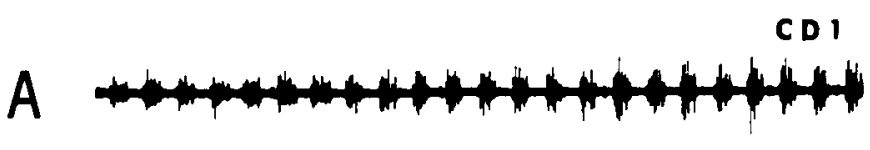

B
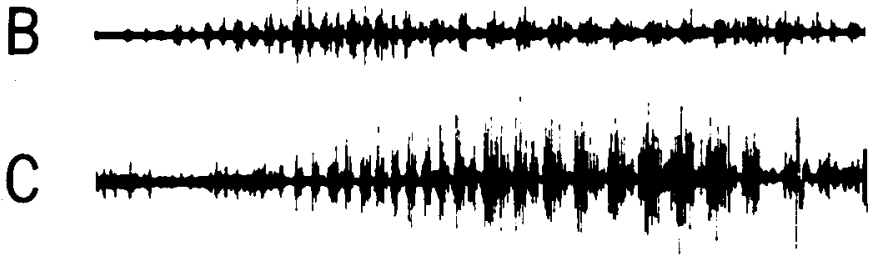

\section{SEC}

Figure 6-EMG recordings from the biceps of the arm following administration of harmaline to a monkey with a midbrain tegmental lesion. A: Recording taken during a period of time in which regular EMG bursts occur at $5 / \mathrm{sec}$. B and C: During two other periods of recording, tremor occurs at two frequencies: $12 / \mathrm{sec}$. and $5 / \mathrm{sec}$.
A

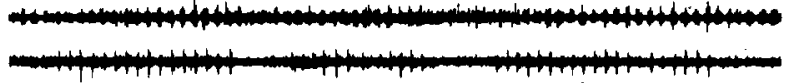

B

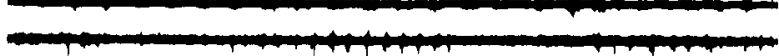

C

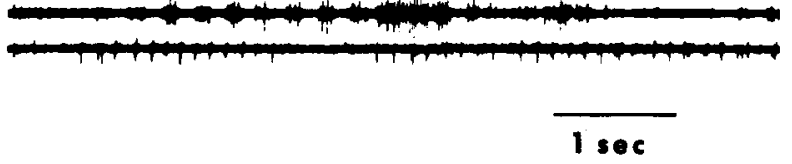

Figure 7-A: EMG recordings from the quadriceps in a normal monkey injected with harmaline (upper trace) and cerebellar recording in the anterior vermis (lower trace). The episodes of cerebellar rhythmic activity at $11 / \mathrm{sec}$. are synchronous with the muscle tremor. B and C: Similar recordings from a monkey with Parkinson-like tremor which had received harmaline. In this case the cerebellar activity has a frequency of about $8 / \mathrm{sec}$. while the muscle trembles at about $4 / \mathrm{sec}$. There is no obvious temporal correlation between the two rhythmic phenomena.
Montigny and Lamarre, 1973; Llinas and Volkind, 1973) which activates simultaneously alpha and gamma motoneurons (Lamarre and Weiss, 1973). Fig. 4 shows the frequency characteristics of this olivocerebellar mechanism. Quadriceps muscle tremor was recorded in a decerebrate cat following the I.V. administration of $5 \mathrm{mg} / \mathrm{kg}$ of harmaline. During tremor, the olivo-cerebellar system was electrically stimulated at various frequencies (parafastigial stimulation). In Fig. 4A, stimulation at $50 / \mathrm{sec}$. inhibits the peripheral tremor, while stimulation at $10 / \mathrm{sec}$. produces EMG bursts at the same frequency (Fig. 4B). There is a one to one relationship between stimulus and response in the frequency range 8.5 to $11 / \mathrm{sec}$. (Fig. 4E). At lower stimulus frequencies, between 5 and $7.5 / \mathrm{sec}$, there is a one to two relationship between stimulus and response as shown in record $\mathrm{D}$ (stimulation at $6.8 / \mathrm{sec}$.) and graph $\mathrm{E}$. Stimulation at around $8 / \mathrm{sec}$. (Fig. 4C) produces a mixed pattern of EMG bursts which seems to contain both high and low frequency components. Such experiments emphasize that the optimal frequency of operation of the olivo-cerebellar system appears to be between 8 and $11 \mathrm{c} / \mathrm{sec}$. Fig. 5 summarizes the tremorgenic pathways involved in the olivo-cerebellar tremor.
Independence between the thalamocortical and olivo-cerebellar tremor mechanisms

The results reported so far indicate that two models of tremor can be studied in animals: one at $3-6 / \mathrm{sec}$., generated at the thalamocortical level and the other, at $7-12 /$ sec., generated by the olivocerebellar system. These two ranges of tremor frequencies are also observed in clinical motor syndromes, (Lance, Schwab and Peterson, 1963; Molina-Negro and Hardy, 1971). Similarly, when harmaline is given to monkeys with Parkinson-like tremor, the rapid $7-12 / \mathrm{sec}$. tremor is often seen in the same muscles displaying the 4-6/sec. tremor. Fig. 6 shows three EMG recordings from the biceps of the arm following administration of harmaline in a monkey with a tegmental lesion. Record A shows regular EMG bursts at $5 / \mathrm{sec}$. In $\mathrm{B}$ and $\mathrm{C}$ tremor occurs at two frequencies, $12 / \mathrm{sec}$. and $5 / \mathrm{sec}$. respectively. Similar observations were made on monkeys with partial cerebellar lesions (Ohye et al., 1970).

As was demonstrated in the cat (De Montigny and Lamarre, 1973; Llinas and Volkind, 1973), the olivo-cerebellar system is also responsible for the fast harmaline tremor in the monkey. Fig. 7A shows simultaneously recorded quadriceps
EMG activity (upper trace) and cerebellar climbing fiber responses (lower trace) in a normal monkey injected with harmaline. The EMG burst activity occurs at $11 / \mathrm{sec}$, and coincides with cerebellar activity at the same frequency. Records in Fig. $7 \mathrm{~B}$ and $\mathrm{C}$ are from another monkey with Parkinson-like tremor which was also injected with harmaline. Bursts occur in the EMG at about $4 / \mathrm{sec}$. (upper traces) but the frequency of the cerebellar rhythmic activity is around $8 / \mathrm{sec}$. (lower traces). In this case, there is no apparent relationship between the two rhythmic phenomena. This is demonstrated more directly in Fig. 8. The top curves show two superimposed autocorrelograms: EMG activity (dotted line) and cerebellar activity (solid line). In contrast to the peaks shown in the autocorrelograms, the crosscorrelograms between these two series of events (lower graph) is flat, indicating that the two types of activity are completely independant. Moreover, ablation or cooling of the motor cortex, as well as lesioning of the thalamus, abolishes the slow Parkinson-like tremor without affecting the fast tremor in the corresponding limbs (Battista, Nakatani, Golstein and Anagnoste, 1970; Jasper et al., 1972; Dumont and Lamarre, 1973). Conversely, in 

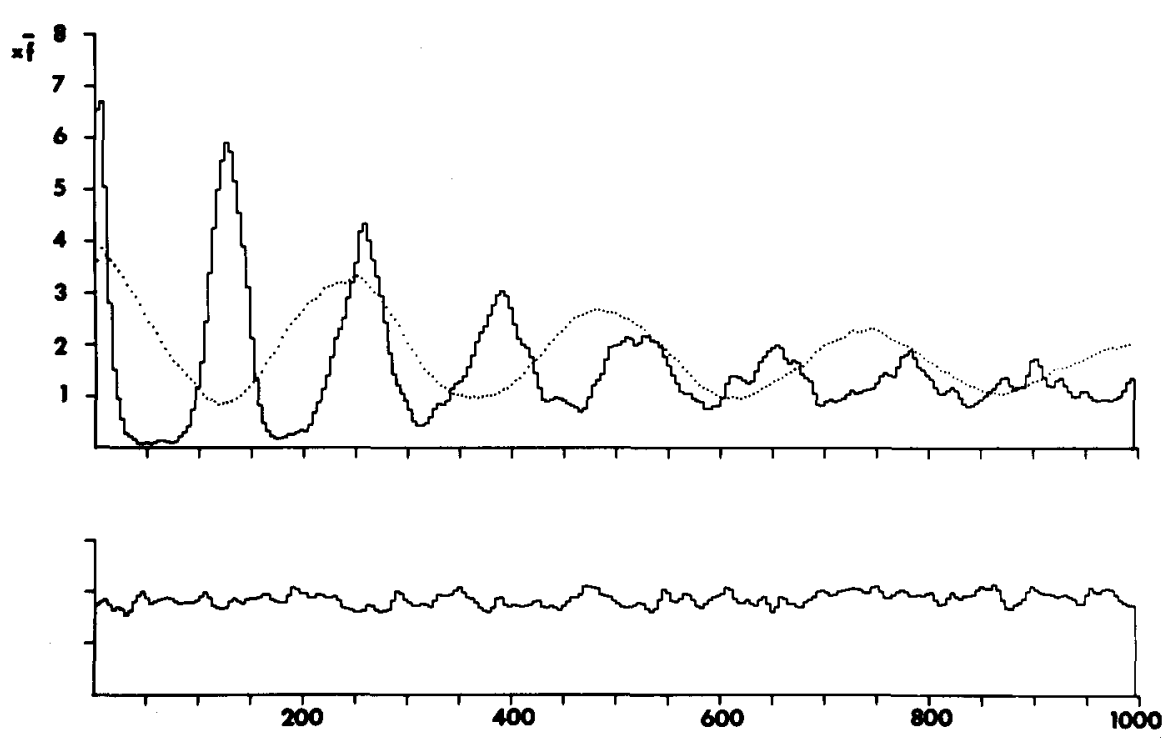

Figure 8-Top: Superimposed autocorrelograms obtained from the animal for which representative recordings are shown in Figure $7 \mathrm{~B}$ and $\mathrm{C}$ (dotted line: muscle tremor; solid line: cerebellar activity). The muscle tremor at $4 / \mathrm{sec}$. is not a sub-harmonic of the $8 / \mathrm{sec}$. cerebellar activity since one obtains a flat line when the two rhythmic activities are crosscorrelated (bottom graph). The units on the ordinates are multiples of the mean frequency of events per second (f).

monkeys with total destruction of the cerebellum (including the deep nuclei) and subsequent degeneration of the inferior olivary neurons, harmaline always induces only the slow tremor $(4-7 / \mathrm{sec}$.) (Lamarre and Dumont, 1972). Finally, we have observed only the fast tremor following administration of harmaline in unanesthetized monkeys decerebrated at the intercollicular level. In this acute preparation, where the two "oscillators" are surgically isolated from one another, harmaline induces sustained rhythms at about $5 / \mathrm{sec}$. in the thalamus and at about $7-9 / \mathrm{sec}$. in the lower brain stem (Lamarre, Lund and Grou, unpublished observations, Fig. 9). These results clearly demonstrate that the two types of tremor are generated by two independent central mechanisms. In their studies of motor abnormalities in Parkinson's disease, Lance et al., (1963) have clearly demonstrated the existence of two forms of tremor: the classical resting tremor at 4-6/sec. (range 3 to 7) and an "action tremor" at 8-10/sec. (range 7 to 12). They stated that "action tremor is considered to have a mechanism distinct from that of the classical resting tremor ..." One of the reasons given was that "resting tremor may be completely abolished by ventrolateral thalamotomy with the preservation of a gross action tremor". This emphasizes the relevance of our experimental tremor models in relationship to the motor disturbances observed in some clinical syndromes.

\section{CONCLUSION}

The experimental results that have been summarized indicate that there exist two independent systems capable of generating peripheral tremor: a thalamo-cortical system and an olivo-cerebellar system. The efferent pathways of these two tremor generators could overlap or be entirely separate (cortico-spinal, cortico-reticulo, and corticovestibulo-spinal; cerebello-reticulo and cerebello-vestibulo-spinal).

The data now available do not allow definite conclusions about the mechanism responsible for the rhythmic activity of these tremor "generators". The action of harmaline upon these rhythm generators is also not understood at the moment. It appears, however, that this drug may act by impairing some very basic cellular mechanisms. Sepulveda and Robinson (1974) reported that harmaline is a potent inhibitor of sodiumdependent transport. Harmaline has also been reported to block sodium transport in the squid nerve axons (Canessa, Jaimovich and de la Fuente, 1973). It is also a potent monoamine oxidase inhibitor (Udenfriend, Witkop, Redfield and Weissback, 1958). However, we have recently demonstrated that this pharmacological property is not responsible for its tremorgenic activity (De Montigny and Lamarre, 1974). Several hypotheses can be offered to explain the generation of central rhythmic activity and the enhancement of this rhythmicity by harmaline. These have been discussed in more detail elsewhere (Lamarre, 1975). In summary, we would like to postulate that harmaline only exaggerates the normal tendency for rhythmicity and synchronization permanently "wired" into the in-

A
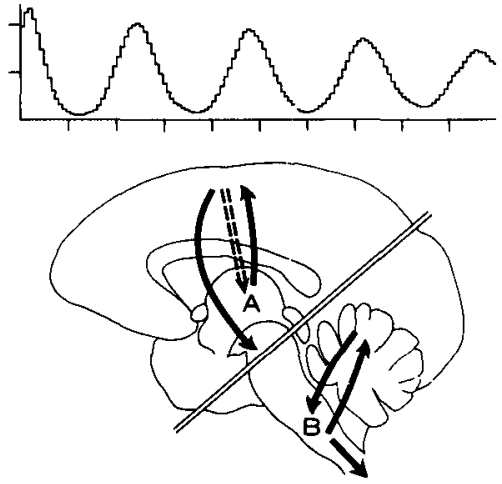

B

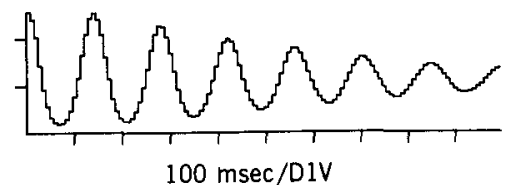

Figure 9-Schematic representation of the two independent central mechanisms responsible for tremor. Unit recordings were obtained in A (Ventrolateral thalamus) and in $\mathbf{B}$ (bulbar reticular formation) in the same unanesthetized monkey, decerebrated at the intercollicular level. In this situation, the two central tremor mechanisms are completely isolated. Rhythmic activity is present at $4.5 / \mathrm{sec}$. in the thalamo-cortical system (autocorrelogram A) and 7.3/sec. (autocorrelogram B). The ordinate scales (events per bin) are in arbitrary units. 
ferior olivary complex. The physiological tremor at $8-12 / \mathrm{sec}$. seen in humans during performance of some motor tasks in closed loop condition (Merton, Morton and Rashbass, 1967; Sutton and Sykes, 1967), might well be due to normal functional synchronization in the olivo-cerebellar system. Within the thalamus, harmaline could also exaggerate abnormal synchronized bursting induced by lesions of afferent pathways.

It is our belief that further investigations of the mechanisms of tremor in animal models may contribute to a better understanding of the physiopathology of tremors in man.

\section{DISCUSSION}

Murphy questioned what effect a basal ganglia lesion might have on VL neurons that fired at $5 / \mathrm{sec}$; i.e. when VL would be driven from the inferior olivo-cerebellar inputs that presumably fire at $10 / \mathrm{sec}$. Why would VL then not fire at $10 / \mathrm{sec}$ ? Was there some internal thalamic mechanism to scale down frequencies? Lamarre reconfirmed that a $10 / \mathrm{sec}$. rhythm was never seen in VL, but rather that it was always $5 / \mathrm{sec}$. He suggested that the cortical cerebellar efferent system of tremor was a descending, such as the olivocerebello-fastigio-bulbo-spinal system, not an ascending system.

Stein (Edmonton) enquired about physiological significance of the "wired in" circuitry said to be responsible for these two tremor frequencies.

Lamarre suggested that the $10 / \mathrm{sec}$. rhythm in the inferior olive might be generated by some type of input to the cerebellum which acts as a chopper, perhaps influencing whether movements are made under closed, as opposed to open, loop conditions.

Lee (Calgary) asked Lamarre to comment on interactions that might occur between tremor at $5 / \mathrm{sec}$., 10/sec., and voluntary activity, maintenance of posture, etc. Lamarre stated that mild "Parkinsonian tremor" in the monkey stops with voluntary movement, at which time motor cortical neurons changed their firing patterns as well; probably because rhythmically firing thalamic neurons then lose their bursting, or rhythmicity, with movement. In view of the lack of effect of dorsal rhizotomy on the two tremor frequencies, Tatton (Calgary) asked whether peripheral inputs can re-set or alter the tremor. Lamarre indicated that various tremors, including the Parkinsonian tremor and the experimental olivary tremor, could be altered by peripheral inputs, but only within certain limits.

Cooke (U.W.O.) commented on work carried out with Thomas in Brooks' laboratory" on arm oscillations and voluntary motor tasks. Normally occurring peak frequency ranges were $3-5 \mathrm{~Hz}$ and 5-7 $\mathrm{Hz}$, but dentate cooling shifted power to the lower frequency bands of 3-5 Hz. Arm oscillations were not reset by voluntary arm movements but instead were merely amplitude-modulated.

In response to a question by Zeldowicz (U.B.C., Vancouver), regarding tremor in sleep, Lamarre responded that tremor disappeared in sleep, like many other clinical extrapyramidal tremors, perhaps due to inhibitory mechanisms associated with onset of sleep.

Barbeau (Montreal) asked how to reconcile the observations on tremor with the demonstration of Brumlik and Boshes of a mechanical ballistocardiographic component in tremor. Lamarre ruled this out since muscle action potentials were grouped at approximately $10 / \mathrm{sec}$.

\section{ACKNOWLEDGEMENTS}

The authors are grateful to Miss C. Laurier, Mr. R. Bouchoux, R. Péloquin and E. Rupnik for their technical assistance.

\section{REFERENCES}

ALBE-FESSARD, D., ARFEL, G., GUIOT, G., DEROME, P., de la HERRAN, J., KORN, H., HERTZOG, E., VOURC'H, G. et ALEONARD, P. (1963). Activités électriques caractéristiques de quelques structures cérébrales chez l'homme. Ann. chir., 17, 1185-1214.

ALBE-FESSARD, D., GUIOT, G. and HARDY, J. (1963). Electrophysiological localization and identification of subcortical structures in man by recording spontaneous and evoked activities. Electroenceph. clin. Neurophysiol., 15, 1052-1053.

ALBE-FESSARD, D., GUIOT, G., LAMARRE, Y. and ARFEL, G. (1966). Activation of thalamo-cortical projections related to tremorgenic processes. In: The thalamus, ed. by Purpura, D. P. and Yahr, M. D., Columbia University Press, New York, pp. 237-253.

ALBERTS, W. W. (1969). Parkinsonian tremor and cerebral potentials. In: Third Symposium on Parkinson's Disease, Livingstone, Edinburgh (Gillingham, F. J. and Donaldson, I. M. L., eds.) pp. 146-149.

ALBERTS, W. W. (1972). A simple view of Parkinsonian tremor. Electrical stimulation of cortex adjacent to the Rolandic fissure in awake man. Brain Res., 44, 357-369.

ALBERTS, W. W., WRIGHT, E. W. and FEINSTEIN, B. (1969). Cortical potentials and Parkinsonian tremor. Nature (London), 221, 670-672.

ARMSTRONG, D. M., ECCLES, J. C., HARVEY, R. J. and MATTHEWS, P. B. C. (1968). Responses in the dorsal accessory olive of the cat to stimulation of hind limb afferents. J. Physiol., London, 194, 125-145.

BATES, J. A. V. (1969). The significance of tremor phasic units in the human thalamus. In: Third Symposium on Parkinson Disease, Livingstone, Edinburgh (Gillingham, F. J. and Donaldson, I. M. L., eds.), pp. 118-124.

BATTISTA, A. F., NAKATANI, S., GOLDSTEIN, M. and ANAGNOSTE, G. (1970). Effect of harmaline in monkeys with central nervous system lesions. Exp. Neurol., 28, 513-524.

BELL, C. C. and KAWASAKI, R. (1972). Relation among climbing fiber responses of nearby Purkinje cells, J. Neurophysiol., 35, 155-169.

CANESSA, M., JAIMOVICH, E. and de la FUENTE, M. (1973). Harmaline: a competitive inhibitor of $\mathrm{Na}$ ion in the $\left(\mathrm{Na}^{+}+\mathrm{K}^{+}\right)-\mathrm{AT}$ Pase system. J. Membrane Biol., 13, 263-282.
CORDEAU, J. P., GYBELS, J., JASPER, H. H. and POIRIER, L. J. (1960). Microelectrode studies of unit discharges in the sensori-motor cortex. Investigations in monkeys with experimental tremor. Neurology, 10, 591-600.

CORDEAU, J. P. and LAMARRE, Y. (1966). Further studies on patterns of central unit activity in relation with tremor. J. Neurosurg., 24, 213-218.

CRILL, W. E. (1970). Unitary multiple-spiked responses in cat inferior olive nucleus. J. Neurophysiol., 33, 199-209.

CROWELL, R. M., PERRET, E., SIEGFRIED, J. and VILLOZ, J. P. (1968). Movement units and tremor phasic units in the human thalamus. Brain Res., 11, 481-488.

De MONTIGNY, C. and LAMARRE, Y. (1973). Rhythmic activity induced by harmaline in the olivo-cerebello-bulbar system of the cat. Brain Res., 53, 81-95.

De MONTIGNY, C. and LAMARRE, Y. (1974). Activity in the olivo-cerebello-bulbar system of the cat during ibogaline- and oxotremorineinduced tremor. Brain Res., 82, 369-373.

DEMPSEY, E. W. and MORISON, R. J. (1942). The production of rhythmically recurrent cortical potentials after localized' thalamic stimulation. Amer. J. Physiol., 135, 293-300.

DUMONT, M. and LAMARRE, Y. (1973). Experimental tremor following CNS lesions in monkeys. Trans. am. neurol. Ass., 98, 37-39.

FERIN, M., GREGORIAN, R. A. and STRATA, P. (1971). Mossy and climbing fiber activation in the cat cerebellum by stimulation of the labyrinth. Exp. Brain Res., 12, 1-17.

GOLDBERGER, M. E. and GROWDEN, J. H. (1971). Tremor at rest following cerebellar lesions in monkeys: effect of L-Dopa administration. Brain Res., 27, 183-187.

HARDY, J. and BERTRAND, C. (1966). Electrophysiological localization and identification. J. Neurosurg., 24, 410-414.

JASPER, H. H. and BERTRAND, G. (1966a). Recording from microelectrodes in stereotaxic surgery for Parkinson's disease. J. Neurosurg., 24, 219-221.

JASPER, H. H. and BERTRAND, G. (1966). Thalamic units involved in somatic sensation and voluntary and involuntary movements in man. In: The thalamus, Columbia University Press (Purpura, D., ed.), 365-384.

JASPER, H. H., LAMARRE, Y. and JOFFROY, A. (1972). The effect of local cooling of the motor cortex upon experimental Parkinson-like tremor, Shivering, voluntary movements, and thalamic unit activity in the Monkey. In: Cortico-thalamic Projections and Sensorimotor Activities, pp. 461-473, ed. by Frigyesi, T., Rinvik, E. and Yahr, M. D., Raven Press, New York.

JOFFROY, A. J. and LAMARRE, Y. (1971). Rhythmic unit firing in the precentral cortex in relation with postural tremor in a deafferented limb. Brain Res., 27, 386-389.

JOFFROY, A. J. and LAMARRE, Y. (1974). Single cell activity in the ventral lateral thalamus of the unanesthetized monkey. Exp. Neurol., 42, 1-16.

KING, J. S., MARTIN, G. F. and BOWMAN, H. H. (1975). The direct spinal area of the inferior olivary nucleus: an electron microscopic study. Exp. Brain Res., 22, 13-24.

LAMARRE, Y. (1975). Tremorgenic mechanisms in primates. Advances in Neurology, (Meldrum, B. S. and Marsden, C. D., eds.), Raven Press, New York, 10, 23-34.

LAMARRE, Y. and CORDEAU, J. P. (1967). Etude du mécanisme physiopathologique responsable chez le Singe, d'un tremblement expérimental de 
type parkinsonien. Actualités neurophysiol., 7, 141-166.

LAMARRE, Y. and DUMONT, M. (1972). Activity of cerebellar and lower brain stem neurons in monkeys with Harmaline-induced tremor. In: Medical Primatology 1972, pp. 274-281, ed. by Goldsmith, E. I. and Moor-Jankowski, J., Karger, Basel.

LAMARRE, Y., FILION, M. and CORDEAU, J. P. (1971). Neuronal discharges of the ventrolateral nucleus of the thalamus during sleep and wakeful. ness in the cat. I - Spontaneous activity. Exp. Brain Res., 12, 480-498.

LAMARRE, Y., De MONTIGNY, C., DUMONT, $M$. and WEISS, M. (1971). Harmaline-induced rhythmic activity of cerebellar and lower brain stem neurons. Brain Res., 32, 246-250.

LAMARRE, Y. and JOFFROY, A. J. (1970). Thalamic unit activity in monkey with experimental tremor. In: L-Dopa and Parkinsonism, pp. 163-170, ed. by Barbeau, $A$. and McDowell, F. H., Davis, Philadelphia.

LAMARRE, Y. and JOFFROY, A. J. (1971). Spontaneous unit activity in the ventrolateral thalamus of the chronic monkey. Int. J. Neurol, , 8, 190-197.

LAMARRE, Y. and WEISS, M. (1973). Harmalineinduced thythmic activity of alpha and gamma motoneurons in the cat. Brain Res., 63, 430-434.

LANCE, J. W., SCHWAB, R. S. and PETERSON, E. A. (1963). Action tremor and the cog wheel phenomenon in Parkinson's disease. Brain, 86, 95-110.

LAROCHELLE, L., BEDARD, P., BOUCHER, R. and POIRIER, L. J. (1970). The rubro-olivocerebello-rubral loop and postural tremor in the monkey. J. neurol. Sci., 11, 53-64.

LEBLANC, F. E. and CORDEAU, J. P. (1969). Modulation of pyramidal tract cell activity by ventrolateral thalamic regions. Its possible role in tremorogenic mechanisms. Brain Res., 14, 255-270.

LLINAS, R., BAKER, R. and SOTELO, C. (1974). Electrotonic coupling between neurons in cat inferior olive. J. Neurophysiol., 37, 560-571.

LLINAS, R. and VOLKIND, R. A. (1973). The olivo-cerebellar system: Functional properties as revealed by harmaline-induced tremor. Exp. Brain Res., 18, 69-87.

MASSION, J., ANGAUT, P. et ALBE-FESSARD, D. (1965). Activités évoquées chez le chat dans la région du nucleus ventralis lateralis par diverses stimulations sensorielles. II. Etude microphysiologique. Electroenceph. clin. Neurophysiol., 19, 452-469.

MERTON, P. A., MORTON, H. B. and RASHBASS, C. (1967). Visual feedback in hand tremor. Nature, 216, 583-584.

MOLINA-NEGRO, P. and HARDY, J. (1971). Etude sémiologique des tremblements. Union Med. Can., 100, 879-895.

OHYE, C., BOUCHARD, R., LAROCHELLE, L., BEDARD, P., BOUCHER, R., RAPHY, B. and POIRIER, L. J. (1970). Effect of dorsal rhizotomy on postural tremor in the monkey. Exp. Brain Res., 10, 140-150.

POIRIER, L. J. (1960). Experimental and histological study of midbrain dyskinesias. J. Neurophysiol., 23, 534-551.

POIRIER, L. J. (1971). "The development of animal models for studies in Parkinson's disease". In: Recent advances in Parkinson's disease, Davis, Philadelphia, Pa. (McDowell, F. H. and Markham, C. H., eds.), pp. 84-117.

POIRIER, L. J., SOURKES, T. L., BOUVIER, G., BOUCHER, R. and CARABIN, S. (1966). Striatal amines, experimental tremor and the effect of harmaline in the monkey. Brain, 89, 37-52.

POLLOCK, L. J. and DAVIS, L. (1930). Muscle tone in Parkinsonian states. Arch. Neurol. Psychiat., (Chic.) 23, 303-319.

PURPURA, D. P. (1969). Interneuronal mechanisms in synchronization and desynchronization of thalamic activity. pp. 467-496. In: The interneuron, ed. by Brazier, M. A. B. Univ. Calif. Press, Los Angeles.

PURPURA, D. P. (1972a). Synaptic mechanisms in coordination of activity in thalamic internuncial common paths. In: Cortico-Thalamic Projections and Sensorimotor activities, pp. 721-751, ed. by Frigyesi, T., Rinvik, E. and Yahr, M. D., Raven Press, New York.

PURPURA, D. P. (1972b). Intracellular studies of synaptic organizations in the mammalian brain. pp. 257-302. In: Structure and function of synapses, ed. by Pappas, G. D. and Purpura, D. P., Raven Press, New York.

SEDGWICK, E. G. and WILLIAMS, T. D. (1967). Responses of single units in the inferior olive to stimulation of the limb nerves, peripheral skin receptors, cerebellum, caudate nucleus and motor cortex. J. Physiol., London, 189, 261-279.

SEPULVEDA, F. V. and ROBINSON, J. W. L. (1974). Harmaline, a potent inhibitor of sodiumdependent transport. Biochimica et Biophysica Acta., 373, 527-531.

SOTELO, C., LLINAS, R. and BAKER, R. (1974). Structural study of inferior olivary nucleus of the cat: morphological correlates of electrotonic coupling. J. Neurophysiol., 37, 541-559.

SUTTON, G. G. and SYKES, K. (1967). The effect of withdrawal of visual presentation of errors upon the frequency spectrum of tremor in a manual task. J. Physiol., London, 190, 281-293.

WALSHE, F. M. R. (1924). Observations on the nature of the muscular regidity of paralysis agitous, and on its relationship to tremor. Brain, 47, 159-177. 